\title{
The Neurotrophic Effects of Fibroblast Growth Factors on Dopaminergic Neurons in vitro Are Mediated by Mesencephalic Glia
}

\author{
Jürgen Engele and Martha Churchill Bohn \\ Department of Neurobiology and Anatomy, University of Rochester Medical Center, Rochester, New York 14642
}

Neurotrophic support is generally believed to result from a direct action of growth factors on developing neurons. However, there is increasing evidence that growth factors can indirectly affect neuronal development by glial-mediated processes. To investigate a possible role of glia in mediating neurotrophic effects on dopaminergic neurons, four purified growth factors were screened for dual effects on the survival and differentiation of dopaminergic neurons and on the proliferation of mesencephalic glial cells in vitro. Dissociated embryonic day 14.5 rat mesencephalon was grown at low cell density without serum, conditions under which both glial growth and neuronal survival are not optimal. Treatment of these cultures with acidic fibroblast growth factor (aFGF) or basic fibroblast growth factor (bFGF) increased the number of surviving tyrosine hydroxylase-immunoreactive (TH-IR) neurons by $190-210 \%$ at $8 \mathrm{~d}$ in vitro in a dose-dependent manner. The effects of these factors were not additive. Highaffinity dopamine uptake was increased by bFGF, but not by aFGF. Length of TH-IR neurites was not affected by either aFGF or bFGF.

Both growth factors induced proliferation of mesencephalic astrocytes as demonstrated by autoradiographic labeling with ${ }^{3} \mathrm{H}$-thymidine combined with immunocytochemistry for glial fibrillary acidic protein (GFAP). In contrast, platelet-derived growth factor (PDGF) and interleukin-1 had no effect on the survival or differentiation of dopaminergic neurons or the proliferation of mesencephalic astrocytes. Inhibition of glial proliferation abolished the neurotrophic effects exerted by aFGF or bFGF on dopaminergic neurons. Moreover, conditioned medium derived from mesencephalic glial cultures replated in the virtual absence of neurons also contained neurotrophic activity.

These observations provide direct evidence that mesencephalic astrocyte precursors are targets for aFGF and bFGF and that these glia provide neurotrophic factors for central dopaminergic neurons.

The majority of neurotrophic factors are small polypeptide molecules that act on specific classes of neurons to support survival and differentiation during development, and survival and re-

\footnotetext{
Received Jan. 18, 1991; revised Mar. 29, 1991; accepted Apr. 24, 1991.

This study was supported by the American Parkinson's Disease Association and the Deutsche Forschungsgemeinschaft En 187/1-1 (J.E.). We thank Dr. T. Maciag for the generous gift of aFGF. The excellent technical assistance of $C$. Hanson and $\mathrm{E}$. Howard is gratefully acknowledged.

Correspondence should be addressed to Martha C. Bohn, Ph.D., Departmen of Neurobiology and Anatomy, Inniversity of Rochester Medical Center, 601 Elmwood Avenue, Box 603, Rochester, NY 14642.

Copyright (C) 1991 Society for Neuroscience $0270-6474 / 91 / 113070-09 \$ 05.00 / 0$
}

gencration in the adult (for review, see Thoenen et al., 1987). In the CNS, the only neurotrophic actions sufficiently characterized are those of $\beta$-NGF on cholinergic neurons of the basal forebrain (for reviews, see Whittemore and Seiger, 1987; Hefti et al., 1989). However, there is increasing evidence that other known growth factors, such as fibroblast growth factor (FGF), affect survival and differentiation of a variety of central neurons (Morrison el al., 1986; Walicke, 1988; Torres-Aleman et al., 1990). In vitro studies have shown that glial cells provide neurotrophic support for central neurons by releasing yet-unidentified substances (Lindsay, 1979; Banker, 1980; Manthorpe et al., 1981; Barbin et al., 1984; Hatanaka and Tsukui, 1986). Moreover, proliferation and differentiation of glia have been found to be affected by a variety of growth factors, among them basic FGF (bFGF) and acidic FGF (aFGF; Pruss et al., 1982; Hatten et al., 1988; Morrison et al., 1988), platelet-derived growth factor (PDGF; Richardson et al., 1988), and interleukin-1 (Giulian et al., 1988).

Previous studies have demonstrated that mesencephalic glia specifically support the survival of dopaminergic neurons (O'Malley et al., 1989) and induce dendritic outgrowth (Chamak et al., 1987). Knusel et al. (1990) recently reported that a stimulation of dopaminergic cell differentiation by epidermal growth factor (EGF) and bFGF can be abolished by blocking cell proliferation. Similarly, our studies have shown that the neurotrophic effects on dopaminergic neurons exerted by conditioned media produced by several glial tumor cell lines are paralleled by an increase in resident mesencephalic astrocytes (Engele et al., 1991).

In the present study, we further examined the possibility that growth factors affect dopaminergic cell development through effects on mesencephalic glia. aFGF, bFGF, PDGF, and interlcukin-1 were screened for effects on development of dopaminergic neurons and proliferation of glia in serum-free, low-density cultures of the embryonic mesencephalon. The role of glial cells in putative neurotrophic effects was characterized by testing (1) growth factors for their survival-promoting effects in mesencephalic cultures with inhibited glial growth and (2) conditioned medium derived from mesencephalic glia for neurotrophic effects on dopaminergic neurons. Effects of the various treatments on the numbers of dopaminergic neurons and astrocytes were assessed by counting tyrosine hydroxylase-immunoreactive (TH-IR) and glial fibrillary acidic protein-immunoreactive (GFAP-IR) cells, respectively. Effects on the differentiation of dopaminergic neurons were assessed by determining neurite length and high-affinity dopamine uptake (Engele et al., 1989). Effects of growth factors on cell proliferation were studied by labeling cultures with ${ }^{3} \mathrm{H}$-thymidine. 


\section{Materials and Methods}

Mesencephalic assay cultures. For establishing mesencephalic assay cultures, two-thirds of the rostral mesencephalon was excised from embryonic day 14.5 (E14.5) Sprague-Dawley rats (Charles River, Kingston; 56-62 somites), trypsinized ( $0.1 \%$ ) for $20 \mathrm{~min}$, and dissociated by trituration. Cells were pelleted at $400 \times g$ for $10 \mathrm{~min}$, resuspended in $90 \%$ minimum essential medium (MEM; Gibco) and $10 \%$ horse serum (Gib$\mathrm{co}$ ), and seeded at a density of 80,000 cells $/ \mathrm{cm}^{2}$ into 48 -well cluster plates (Costar) coated with poly-L-lysine $(0.1 \mathrm{mg} / \mathrm{ml}, \mathrm{MW} 30,000-70,000$; Sigma). After $16 \mathrm{hr}$, cultures were rinsed three times with serum-free MEM/F12 (1:1, v/v; Gibco) and maintained for $7 \mathrm{~d}$ in a modified N2 medium (Bottenstein and Sato, 1979) consisting of MEM/F12 (1:1) supplemented with glucose ( $5 \mathrm{gm} / \mathrm{liter})$, glutamine ( $220 \mathrm{mg} / \mathrm{liter})$, HEPES $(10 \mathrm{~mm})$, transferrin $(50 \mu \mathrm{g} / \mathrm{ml})$, putrescine $\left(10^{-4} \mathrm{M}\right)$, insulin $(5 \mu \mathrm{g} / \mathrm{ml})$, triidothyronine $\left(5 \times 10^{-10} \mathrm{M}\right)$, sodium selenite $\left(3 \times 10^{-8} \mathrm{M}\right)$, progesterone $\left(2 \times 10^{-8} \mathrm{M}\right)$, and gentamicin $(50 \mu \mathrm{g} / \mathrm{ml})$ with medium changes every second day. After $1 \mathrm{~d}$ in vitro (DIV; day of plating $=$ day 0 ), cultures were treated with aFGF (human recombinant; kindly provided by Dr. T. Maciag), bFGF (bovine brain extract; Collaborative Research), platelet-derived growth factor (PDGF; Sigma), or interleukin-1 (a gift from Glaxo). The treatment was repeated with every medium change.

To test growth factors for neurotrophic effects in the "absence of glia," glial proliferation was inhibited by treating cultures on day 2 of cultivation for $24 \mathrm{hr}$ with ${ }^{3} \mathrm{H}$-thymidine $(4 \mu \mathrm{Ci} / \mathrm{ml}$; specific activity, $45 \mathrm{Ci}$ / mmol; Amersham).

Mesencephalic glial cultures and preparation of conditioned medium. To establish cultures from embryonic mesencephalic glia, glial proliferation in E14.5 mesencephalic cultures was stimulated with aFGF (50 $\mathrm{ng} / \mathrm{ml})$ and heparin $(2.5 \mathrm{U} / \mathrm{ml})(\mathrm{J}$. Engele and M. C. Bohn, unpublished observations). After $7 \mathrm{~d}$ in vitro (DIV), the stimulated cells were dislodged enzymatically $(0.1 \%$ trypsin), replated at a density of 200,000 cells $/ \mathrm{cm}^{2}$ into poly-L-lysine-coated culture dishes, and cultivated in serum-free N2 medium.

Conditioned medium (CM) was obtained by incubating mesencephalic glial cultures on day 2 after replating with serum-free $\mathrm{N} 2$ medium $\left(200 \mu \mathrm{l} / \mathrm{cm}^{2}\right)$. After $48 \mathrm{hr}$, the medium was collected, and cells and cell debris were removed by centrifugation at 1000 and $3000 \times g$, respectively. CM was aliquoted and stored at $-80^{\circ} \mathrm{C}$.

Immunocytochemistry. For staining with TH antiserum (1:750; Eugene Tech), cultures were fixed for 20 min with $2 \%$ cacodylatc-buffered $(50 \mathrm{~mm}, \mathrm{pH} 7.3$ ) glutaraldehyde and treated for $5 \mathrm{~min}$ with $1 \%$ sodium borohydride. For staining with antisera against GFAP (1:1000; Accurate); 2',3'-cyclic nucleotide 3'-phosphohydrolase (CNP, 1:750; a gift from Dr. F. A. McMorris); vimentin (Boehringer); the 68, 160, and 200 $\mathrm{kDa}$ neurofilament proteins (NF; Boehringer); Leucocyte common antigen (LCA $=\mathrm{Ox} \mathrm{1;} \mathrm{1:300;} \mathrm{Serotec);} \mathrm{or} \mathrm{fibronectin} \mathrm{(Rockland),} \mathrm{cultures}$ were fixed for $20 \mathrm{~min}$ with $4 \%$ PBS-buffered (100 mM) paraformaldehyde. In all cases, cells were permeabilized for $30 \mathrm{~min}$ with $0.1 \%$ saponine and incubated for $48 \mathrm{hr}$ at $4^{\circ} \mathrm{C}$ with the primary antibody and for another $2 \mathrm{hr}$ at $20^{\circ} \mathrm{C}$ with a biotinylated secondary antibody (1:400; Vector). Labeling was detected using the Vectastain ABC kit (Vector Labs) and 3-3'-diaminobenzidine as a chromagen.

Morphometric analysis. The survival of dopaminergic neurons was determined by counting all $\mathrm{TH}$-immunoreactive (TH-IR) neurons per culture well. As an index for neurite length of a TH-IR neuron, the total number of intersections of TH-IR neurites with a reticule grid $(1 \times 1$ $\mathrm{cm}$, subdivided into 100 squares) was determined at a $200 \times$ magnification in 10 randomly chosen observation fields (total area, $2.5 \mathrm{~mm}^{2}$ ) per well and divided by the number of TH-IR somata present in the examined area. GFAP-IR cells were counted in 10 randomly chosen observation fields per well (total area, $2.5 \mathrm{~mm}^{2}$ ). NF-IR cells were counted in five randomly chosen observation fields per well (total area, 1.25 $\mathrm{mm}^{2}$ ).

High-affinity dopamine uptake. Cultures were incubated at $37^{\circ} \mathrm{C}$ with $5 \times 10^{-8} \mathrm{M}^{3} \mathrm{H}$-dopamine (specific activity, 44-49 Ci $/ \mathrm{mmol}$; Amersham) in the presence of ascorbic acid $(100 \mu \mathrm{M})$, fluoxetine ( $1 \mu \mathrm{M}$; Lilly), and desipramine ( $1 \mu \mathrm{M}$; Sigma). After $30 \mathrm{~min}$, cultures were rinsed three times, and the radioactivity associated with the cells was determined in an SDS lysate by liquid scintillation counting. Nonspecific ${ }^{3} \mathrm{H}$-dopamine accumulation was determined in the presence of a 1000-fold excess of unlabeled transmitter. The dopamine-sensitive part of the uptake was considered as specific ${ }^{3} \mathrm{H}$-dopamine uptake and divided by the number of TH-IR neurons determined in sister cultures (Engele et al., 1989; Reisert et al., 1989).

Autoradiography. Cultures were treated with ${ }^{3} \mathrm{H}$-thymidine $(1 \mu \mathrm{Ci}$ / $\mathrm{ml}$ ) at 48 and $24 \mathrm{hr}$ prior to fixation. Cultures stained for GFAP-IR were exposed at $4^{\circ} \mathrm{C}$ to Kodak NTB2 photographic emulsion and developed after $7 \mathrm{~d}$.

Statistics. Unless stated otherwise, the data are the average from four to six cultures \pm SD. Data were submitted to a one-way analysis of variance (ANOVA), and the significance of intergroup differences was determined by applying Student's $t$ test. Differences were considered significant at $p \leq 0.05$.

\section{Results}

Effect of growth factors on survival and differentiation of dopaminergic neurons

The number of TH-IR neurons in low-density mesencephalic cultures, maintained for $8 \mathrm{~d}$ under previously established serumfree culture conditions (Engele et al., 1991), increased 1.9-2.1fold after treatment with aFGF or bFGF (Figs. 1, 2). These effects were dose dependent and required half-maximal concentrations of about $3 \mathrm{ng} / \mathrm{ml}$ of bFGF and $5 \mathrm{ng} / \mathrm{ml}$ of aFGF. Treatment of the cultures with a combination of aFGF and bFGF provided no additive effects on dopaminergic cell survival (Table 1). Previous experiments have shown that heparin potentiates the biological effects of aFGF (Neufeld et al., 1987). However, addition of heparin with aFGF to these low-density cultures caused the cells to form aggregates, and it was not possible to count the number of surviving TH-IR neurons under this condition. Dopaminergic cell survival was also not affected by PDGF or interleukin-1 (Fig. 1).

The effects of these growth factors on the differentiation of dopaminergic neurons were determined by estimating neurite length and high-affinity dopamine uptake after treatment with concentrations of aFGF and bFGF having maximal effects on dopaminergic cell survival (Fig. 3). A small, 1.6-fold increase in neurite length in the presence of aFGF or bFGF was not statistically different from controls. ${ }^{3} \mathrm{H}$-dopamine uptake per TH-IR neuron was about two times higher in cultures maintained in the presence of bFGF, whereas in aFGF-treated cultures, ${ }^{3} \mathrm{H}$-dopamine uptake was not statistically different from control levels. Neither PDGF ( $8 \mathrm{ng} / \mathrm{ml}$ ) nor interleukin-l (2 ng/ $\mathrm{ml}$ ) affected neurite length or ${ }^{3} \mathrm{H}$-dopamine uptake.

\section{Effect of growth factors on mesencephalic glia}

To study the effects of growth factors on astrocytes, cultures were immunocytochemically stained for the astroglial marker GFAP. The number of GFAP-IR cells increased four to five times in cultures maintained in the presence of bFGF $(10 \mathrm{ng} /$ $\mathrm{ml}$ ) or aFGF $(50 \mathrm{ng} / \mathrm{ml})$ (Table 2). PDGF $(8 \mathrm{ng} / \mathrm{ml})$ and interleukin-1 $(2 \mathrm{ng} / \mathrm{ml})$ had no effect on the number of GFAP-IR cells in culture. In cultures maintained in the presence and absence of growth factors, GFAP-IR was expressed by two distinct populations of glial cells. The majority of cells was characterized by a stellate morphology similar to type- 2 astrocytes. Another smaller population possessed one to two long processes and resembled radial glia (Fig. $4 A, B$ ). Only a few flat, type-1-like astrocytes were present, and these never displayed GFAP immunoreactivity.

To determine whether the increase in number of GFAP-IR cells was due to glial proliferation or to an improved survival, proliferating cells were labeled with ${ }^{3} \mathrm{H}$-thymidine $(1 \mu \mathrm{Ci} / \mathrm{ml}$ for $48 \mathrm{hr}$ ). Autoradiograms of these cultures showed that the labeling index of GFAP-IR astrocytes for ${ }^{3} \mathrm{H}$-thymidine was $6-$ 10 times higher in cultures treated with aFGF or bFGF compared to controls (Table 2, Fig. 4). In addition, both growth factors significantly increased the percentage of non-GFAP-IR cells exhibiting silver grains over their nuclei, with the greatest 

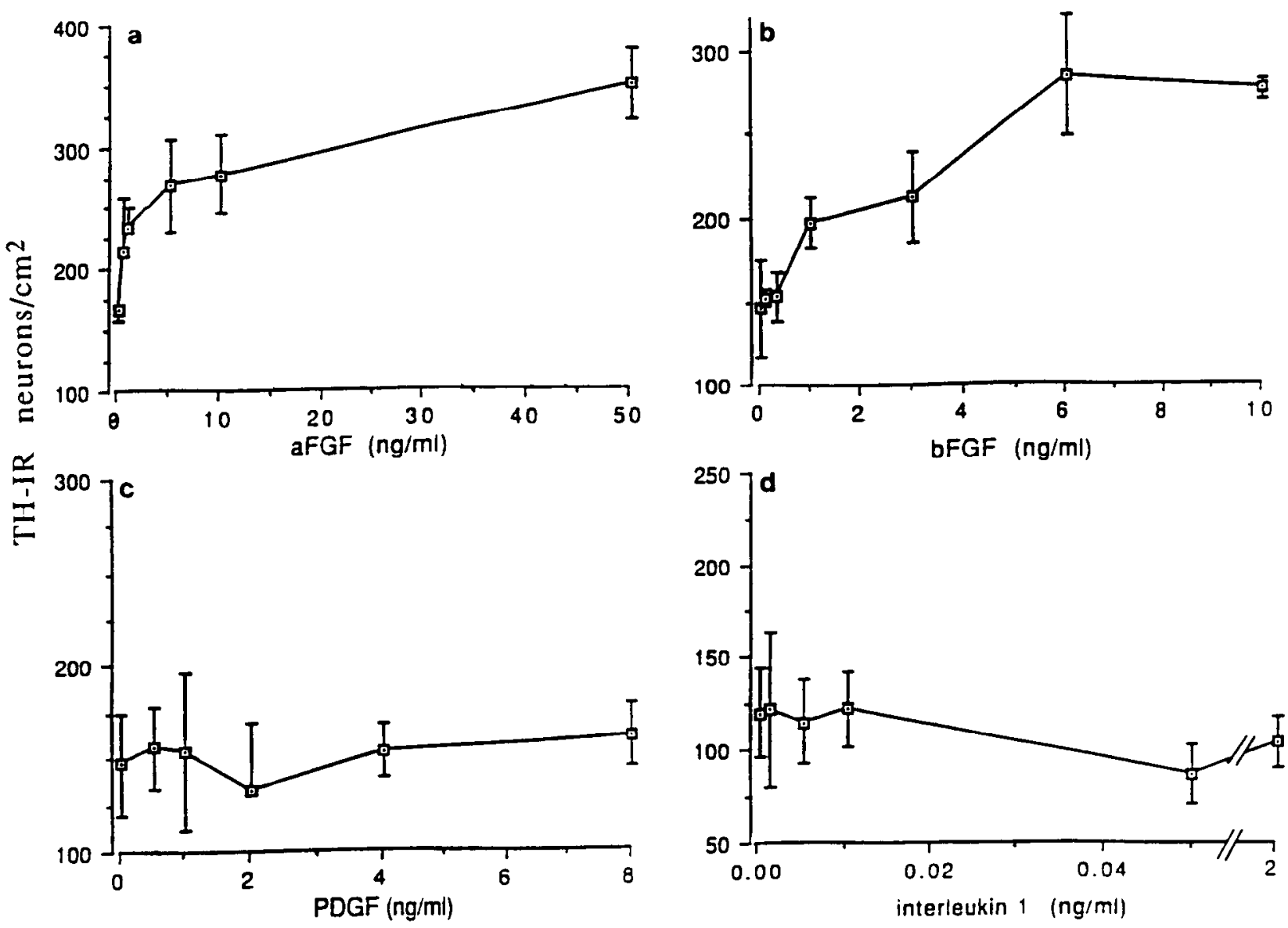

Figure 1. Dose-response effects of aFGF $(a), \operatorname{bFGF}(b), \operatorname{PDGF}(c)$, and interleukin-1 $(d)$ on survival of dopaminergic neurons. E14.5 mesencephalic cells were seeded at a density of 80,000 cells $/ \mathrm{cm}^{2}$ and cultivated in serum-free $\mathrm{N} 2$ medium and varying concentrations of purified growth factors. After 8 DIV, cultures were fixed and dopaminergic neurons were identified by TH immunocytochemistry. Values are expressed as the mean \pm SD $(n=4-6)$. Significant increases in the number of surviving TH-IR neurons were observed in the presence of aFGF $(F=15.8, \mathrm{df} 23, p \leq 0.0001)$ and $\mathrm{bFGF}(F=23.5, \mathrm{dF} 27, \mathrm{p} \leq 0.0001)$.

increase elicited by bFGF. In all cases, about one-half of the non-GFAP-IR cells were characterized by an epitheloid morphology, resembling type-1 astrocytes, while the other half expressed a fibrous morphology similar to type- 2 astrocytes.

Neurotrophic effects of aFGF and bFGF in cultures with inhibited glial proliferation

To reveal the role of mesencephalic glia in the neurotrophic effects of aFGF and bFGF on dopaminergic neurons, both growth

\section{Table 1. Effect of combined treatments with aFGF and bFGF on dopaminergic cell survival}

TH-IR

Treatment neurons $/ \mathrm{cm}^{2}$

Control $108 \pm 11$

aFGF $(50 \mathrm{ng} / \mathrm{ml})$

bFGF $(6 \mathrm{ng} / \mathrm{ml})$

$\mathrm{aFGF}(50 \mathrm{ng} / \mathrm{ml})+\mathrm{bFGF}(6 \mathrm{ng} / \mathrm{ml})$

$178 \pm 9^{a}$

$268 \pm 9^{\prime}$

$241 \pm 40^{a}$

For description see Figurc 1. Combined treatment with growth factors did not significantly increase the number of TH-IR neurons when compared to individual treatments.

$" p \leq 0.001$, treatment versus control.

${ }^{h} p \leq 0.01$, treatment versus control. factors were tested for their survival-promoting effects in mesencephalic cultures with inhibited glial proliferation. Previous attempts to inhibit glial proliferation in serum-free mesencephalic cultures plated at low cell density with cytosine arabinoside (ARA-C) or arabine arabinoside (ARA-A) showed that both substances are neurotoxic under these conditions (Engele et al., 1991). Therefore, we used ${ }^{3} \mathrm{H}$-thymidine as a mitotic inhibitor for cultured glia. As a result of the short-range radiation of $\beta$-particles, it is expected that at a certain concentration of ${ }^{3} \mathrm{H}$-thymidine the toxicity of the treatment is fairly low on nonproliferating cells but that it is high on proliferating cells that actively accumulate the isotope in their nuclei (Feinendegen, 1967). Treatment of 2-d-old mesencephalic cultures with ${ }^{3} \mathrm{H}$ thymidine at a concentration of $4 \mu \mathrm{Ci} / \mathrm{ml}$ totally abolished the aFGF- and bFGF-induced increase in the number of GFAP-IR astrocytes (Fig. 5A). Moreover, the treatment had no effect on the number of surviving TH-IR neurons in control cultures (Fig. $5 B$ ), suggesting that ${ }^{3} \mathrm{H}$-thymidine concentration does not interfere with the survival of cultured dopaminergic neurons per se. When cultures were treated with $10 \mu \mathrm{Ci} / \mathrm{ml}$ of ${ }^{3} \mathrm{H}$-thymidine, a substantial $(60 \%)$ decrease in the number of surviving TH-IR neurons was observed. Concentrations of ${ }^{3} \mathrm{H}$-thymidine of 1 and $2 \mu \mathrm{Ci} / \mathrm{ml}$ did not prevent the growth factor-induced glial proliferation. Similarly, treatment of mesencephalic cultures with 

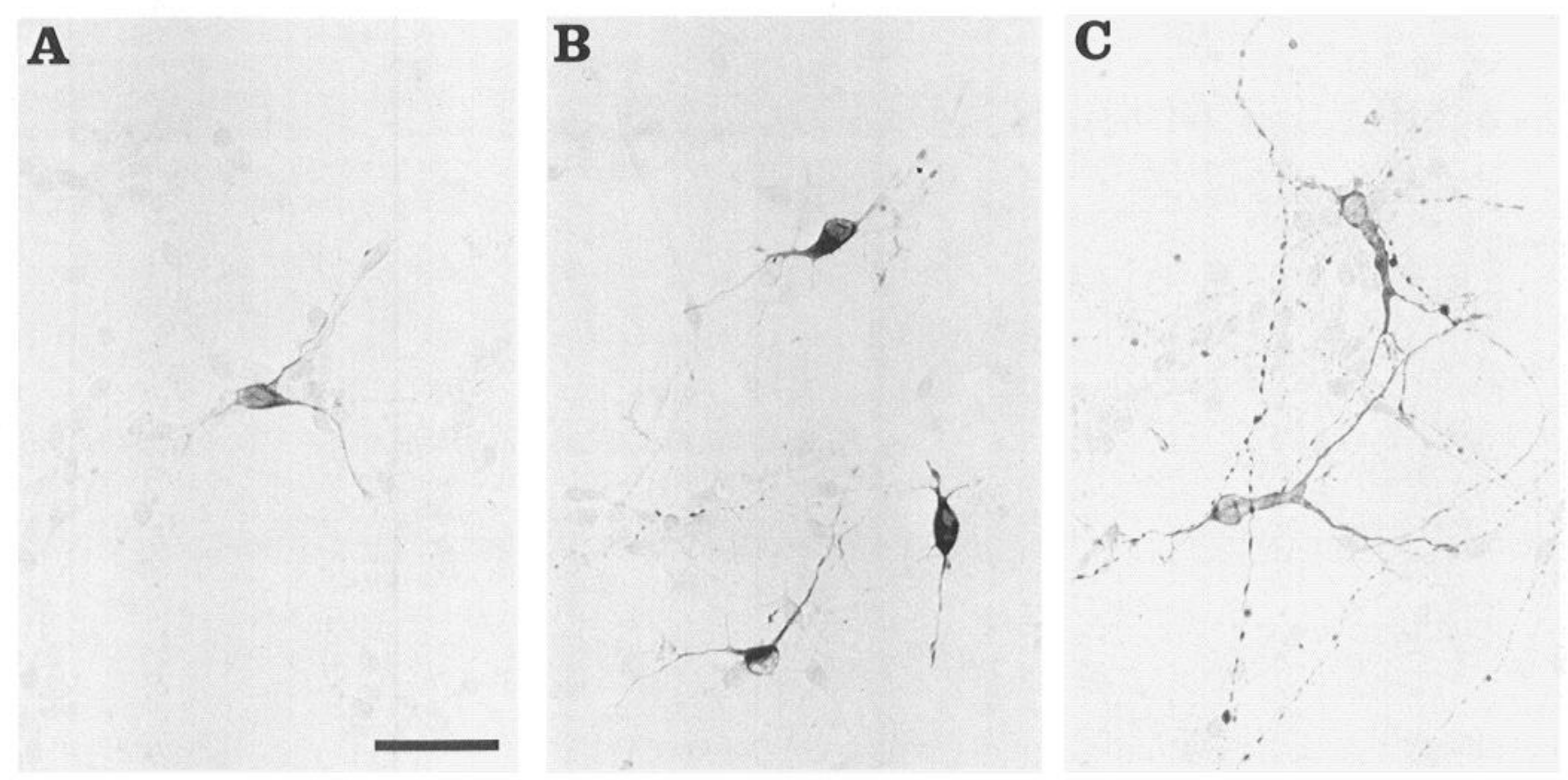

Figure 2. TH-IR neurons in 8-d-old cultures of the E14.5 mesencephalon. $A$, Control; $B$, aFGF ( $50 \mathrm{ng} / \mathrm{ml}) ; C$, glial CM (60\%). Scale bar, $50 \mu \mathrm{m}$.

$4 \mu \mathrm{Ci} / \mathrm{ml}$ of the isotope did not affect the total number of NFIR neurons (Table 3 ).

Addition of aFGF and bFGF to cultures in which glial proliferation was inhibited with $4 \mu \mathrm{Ci} / \mathrm{ml}$ of ${ }^{3} \mathrm{H}$-thymidine failed to support dopaminergic cell survival (Fig. $5 B$ ), suggesting that the survival-promoting effects of both growth factors are mediated by resident mesencephalic glia.

\section{Effect of medium conditioned by mesencephalic glia on dopaminergic cell survival}

To determine whether mesencephalic glia support dopaminergic cell survival by a releasable factor, medium conditioned by embryonic mesencephalic glia was tested for neurotrophic effects on dopaminergic neurons. In low-density mesencephalic cultures maintained in the presence of aFGF $(50 \mathrm{ng} / \mathrm{ml})$ and heparin $(2.5 \mathrm{U} / \mathrm{ml})$, proliferating cells had completely overgrown the culture dish after 7 DIV. Cultures obtained after replating the aFGF and heparin-stimulated cells contained less than $1 \%$ NF-IR neurons and were free of fibronectin-IR fibroblasts and LCA (Ox1)-IR microglial cells (Table 4). About 63\% of the replated cells expressed vimentin-IR, a marker for glial cells (Schnitzer et al., 1981). Moreover, $35 \%$ of the cells were immunoreactive for the astrocytic marker GFAP and had a stellate morphology (Fig. $6 A$ ), and about $15 \%$ of the cells expressed the oligodendroglial marker CNP and possessed a differentiated oligodendroglia-like morphology (Fig. 6B).

When CM derived from aFGF and heparin-stimulated mesencephalic glia after replating was included in low-density E14.5 mesencephalic cultures, the survival of TH-IR neurons increased in a dose-dependent manner (Figs. $2 C, 7$ ). This increase was 2.2 -fold with $60 \%$ glial $\mathrm{CM}$. Moreover, glial $\mathrm{CM}$ induced a 3 times greater outgrowth of TH-IR neurites $(35.0 \pm 3.2$ intersections/TH-IR neuron with glial CM vs. $11.6 \pm 1.4$ intersections/TH-IR neuron in controls; $p \leq 0.001$ ). Importantly, treatment of mesencephalic cultures with glial $\mathrm{CM}$ did not result in a general increase in the number of NF-IR neurons (Table $3)$.

To test whether the survival promoting effect of mesencephalic glial CM on dopaminergic neurons is paralleled by an increase in glial cell number, the glial CM was tested for mitotic

\section{Table 2. Effect of growth factors and glial $\mathrm{CM}$ on glial proliferation}

\begin{tabular}{|c|c|c|c|c|c|c|}
\hline & Control & $\begin{array}{l}\mathrm{aFGF} \\
(50 \mathrm{ng} / \mathrm{ml})\end{array}$ & $\begin{array}{l}\text { bFGF } \\
(10 \mathrm{ng} / \mathrm{ml})\end{array}$ & $\begin{array}{l}\text { PDGF } \\
(8 \mathrm{ng} / \mathrm{ml})\end{array}$ & $\begin{array}{l}\text { Interleukin-1 } \\
(2 \mathrm{ng} / \mathrm{ml})\end{array}$ & $\begin{array}{l}\text { Glial CM } \\
(60 \%)\end{array}$ \\
\hline GFAP-IR cells $/ \mathrm{cm}^{2}$ & $611 \pm 141$ & $2205 \pm 160^{a}$ & $2760 \pm 283^{a}$ & $605 \pm 41(\mathrm{NS})$ & $643 \pm 39(\mathrm{NS})$ & $641 \pm 107(\mathrm{NS})$ \\
\hline GFAP/33-thymidine (\%) & $5.1 \pm 3.4$ & $50.8 \pm 7.6^{a}$ & $31.3 \pm 3.7^{b}$ & - & - & $4.0 \pm 2.6(\mathrm{NS})$ \\
\hline
\end{tabular}

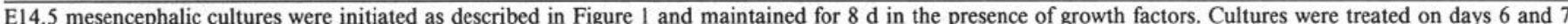

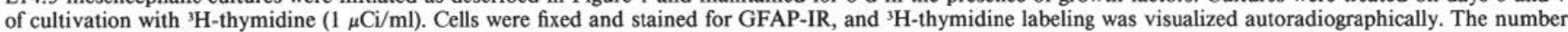

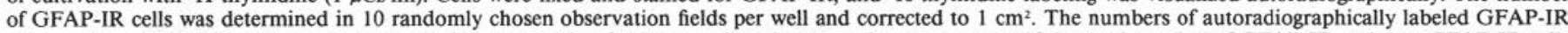

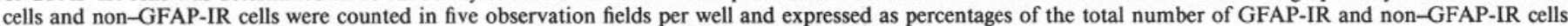
in the examined area, respectively. Values are expressed as the mean $\pm \operatorname{SD}(n=4)$. NS, not significant.

${ }^{a} p \leq 0.01$.

${ }^{b} p \leq 0.001$. Treatment versus control. 

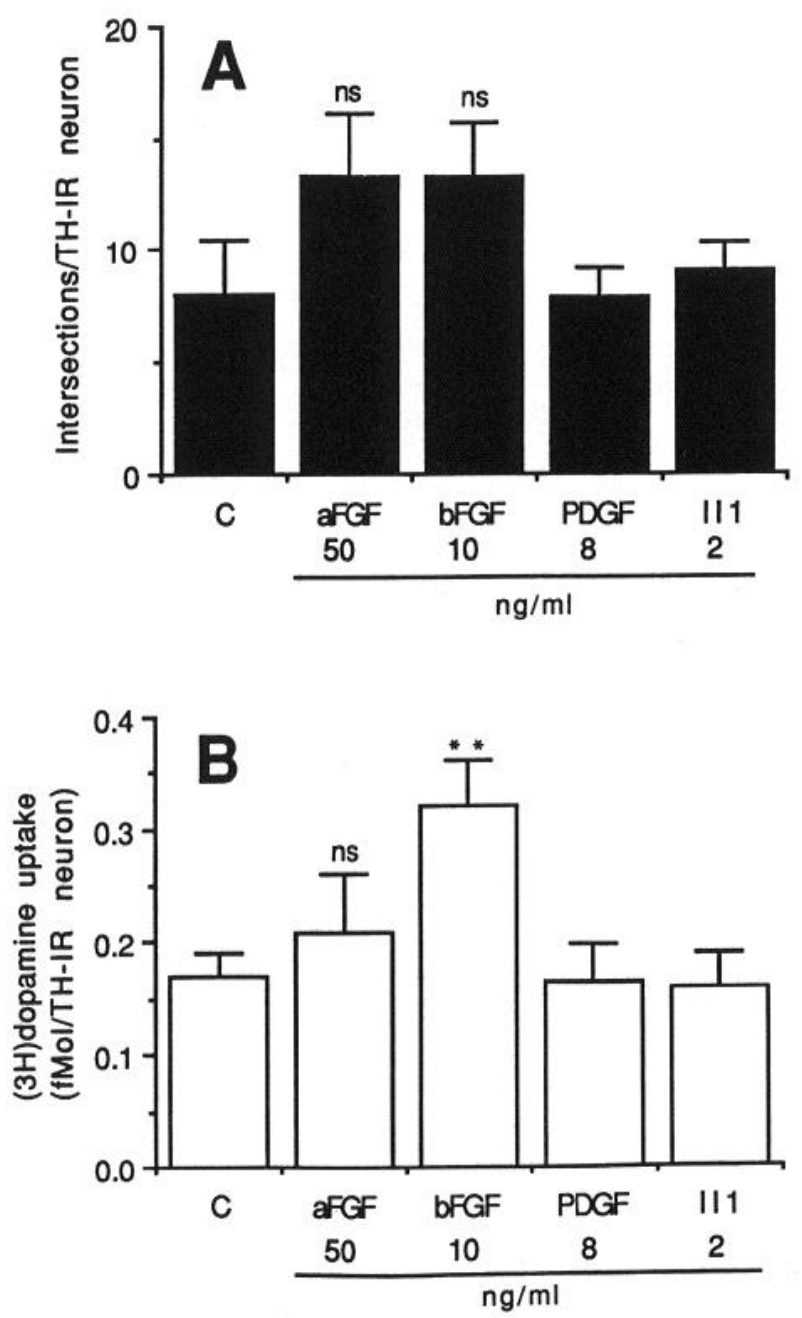

effects on cultured mesencephalic cells. In cultures treated with glial CM, both the number of GFAP-IR astrocytes and the labeling index of GFAP-IR cells and non-GFAP-IR cells for ${ }^{3} \mathrm{H}$-thymidine $(1 \mu \mathrm{Ci} / \mathrm{ml})$ were not significantly different from control cultures (Table 2). Moreover, the glial CM-induced increase in dopaminergic cell survival persisted in cultures in which glial proliferation was inhibited by high concentrations $(4 \mu \mathrm{Ci} / \mathrm{ml})$ of ${ }^{3} \mathrm{H}$-thymidine (Fig. 7). This suggests that the neurotrophic activity contained in the $\mathrm{CM}$ acts directly on cultured mesencephalic neurons rather than via glia.

\section{Discussion}

In a previous study, we observed that $\mathrm{CM}$ derived from several glial lines not only enhance dopaminergic cell survival and differentiation but also stimulate proliferation of mesencephalic glia (Engele et al., 1991). In the present study, we addressed the question whether purified growth factors exert similar dual effects on dopaminergic cell survival and glial proliferation. Exposure of serum-free, low-density cultures of the embryonic

Figure 3. A, Effect of growth factors on neurite-length of dopaminergic neurons. E14.5 mesencephalic cultures were initiated as described in Figure 1 and maintained in the presence of purified growth factors. After 8 DIV, cells were fixed and stained with TH antiserum. The number of intersections of TH-IR neurites with a reticule grid $(1 \times 1 \mathrm{~cm}$, subdivided into 100 squares) was determined in 10 randomly chosen observation fields per well and was divided by the number of TH-IR somata present in the examined area. Values are expressed as the mean $\pm \mathrm{SD}(n=3)$. $B$, Effects of growth factors on ${ }^{3} \mathrm{H}$-dopamine uptake. E14.5 mesencephalic cells were seeded at 80,000 cells $/ \mathrm{cm}^{2}$ and cultured for $8 \mathrm{~d}$ in the presence of the indicated concentrations of growth factors. Specific ${ }^{3} \mathrm{H}$-dopamine uptake was determined within $30 \mathrm{~min}$ as described in Materials and Methods. Values are expressed as the mean \pm $\mathrm{SD}(n=12){ }^{* *}, p \leq 0.01$. $n s$, not significant.
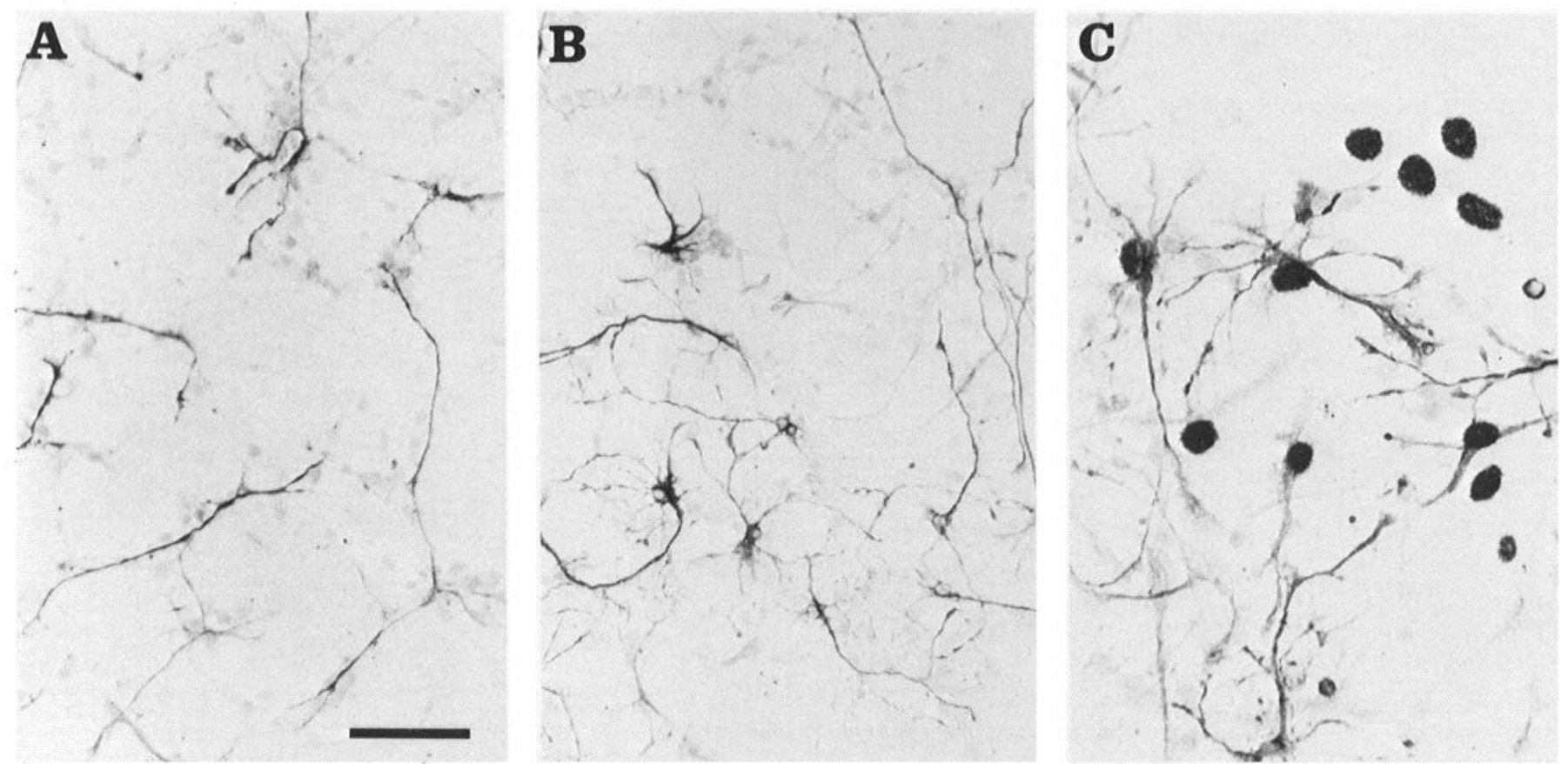

Figure 4. A, GFAP-IR astrocytes in 8-d-old mesencephalic cultures maintained in serum-free N2-medium. $B$, GFAP-IR astrocytes in mesencephalic cultures treated with bFGF $(10 \mathrm{ng} / \mathrm{ml})$. See text for details. $C$, GFAP-IR astrocytes in bFGF-treated cultures showing autoradiographic labeling for ${ }^{3} \mathrm{H}$-thymidine. Note that ${ }^{3} \mathrm{H}$-thymidine labeling is not restricted to GFAP-IR cells. $C$, Scale bar: $A$ and $B, 100 \mu \mathrm{m} ; C, 50 \mu \mathrm{m}$. 

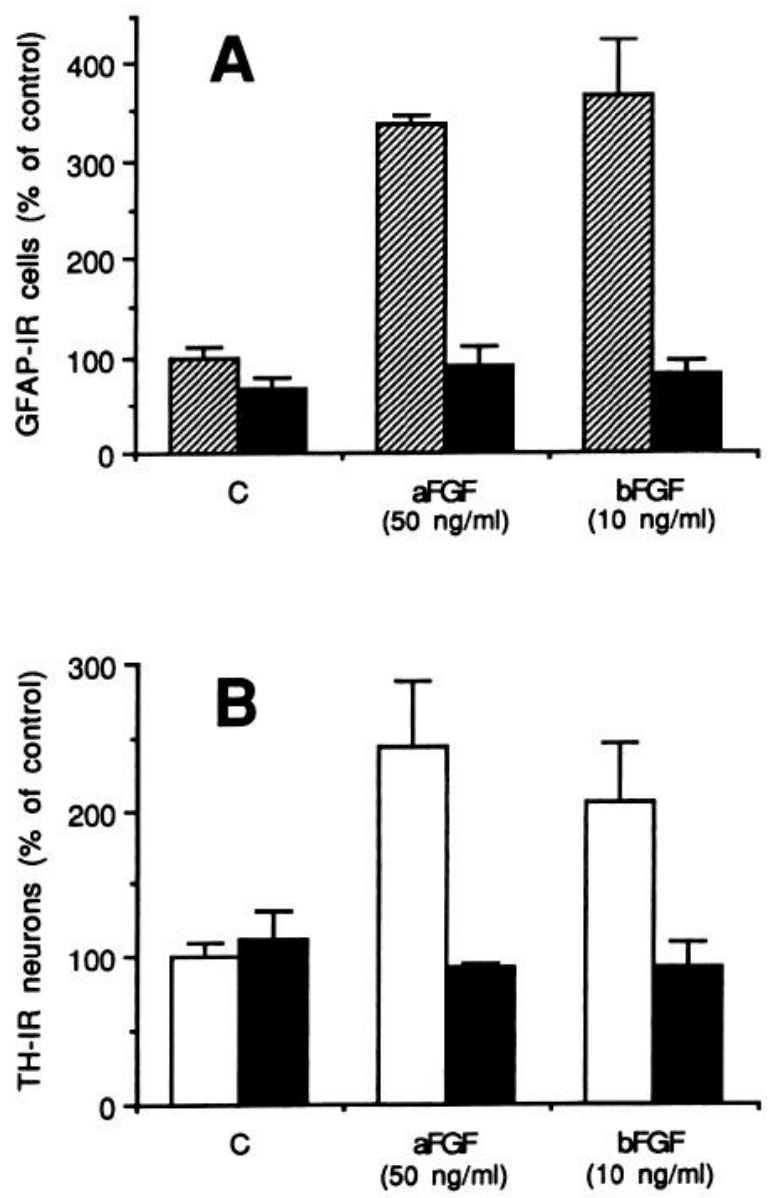

Figure 5. A, Effect of aFGF and bFGF on the number of GFAP-IR astrocytes in control cultures (hatched bars) and in cultures treated with high concentrations of ${ }^{3} \mathrm{H}$-thymidine (solid bars). Dissociated cell cultures were initiated from the E14.5 mesencephalon as described in Figure 1 and maintained in the presence of growth factors. Cultures were treated on day 2 of cultivation for $24 \mathrm{hr}$ with ${ }^{3} \mathrm{H}$-thymidine $(4 \mu \mathrm{Ci} / \mathrm{ml})$. The number of GFAP-IR astrocytes was determined after 8 DIV as described in Figure 5. B, Number of surviving TH-IR neurons in cultures with noninhibited glia proliferation (open bars) and in cultures with inhibited glial proliferation (solid bars). Cultures were treated as described in $A$, and TH-IR neurons were quantified after 8 DIV. Note that treatment with ${ }^{3} \mathrm{H}$-thymidine did not affect the survival of TH-IR neurons in control cultures. Values are expressed as mean $\pm \operatorname{SD}(n=$ 4-6).

mesencephalon to aFGF and bFGF enhanced dopaminergic cell survival and increased the number of astrocytes. The neurotrophic effect of both growth factors was abolished in cultures with inhibited glial proliferation. Moreover, the survival-promoting effects of aFGF and bFGF on dopaminergic neurons could be mimicked by treating E14.5 mesencephalic mixed neuronal-glial cultures with $\mathrm{CM}$ derived from purified mesencephalic glia. Similarly, dopaminergic cell survival was not supported by PDGF or interleukin-1, factors which also did not affect glial proliferation. Taken together, our observations suggest that mesencephalic glia provide a neurotrophic factor(s) for dopaminergic neurons that is distinct from aFGF, bFGF, interleukin-1, or PDGF. Furthermore, the apparent effects of aFGF and bFGF on dopaminergic neurons in these cultures probably occur through increasing the amount of this yet-unknown glial factor by stimulating the proliferation of mesencephalic glial precursors.
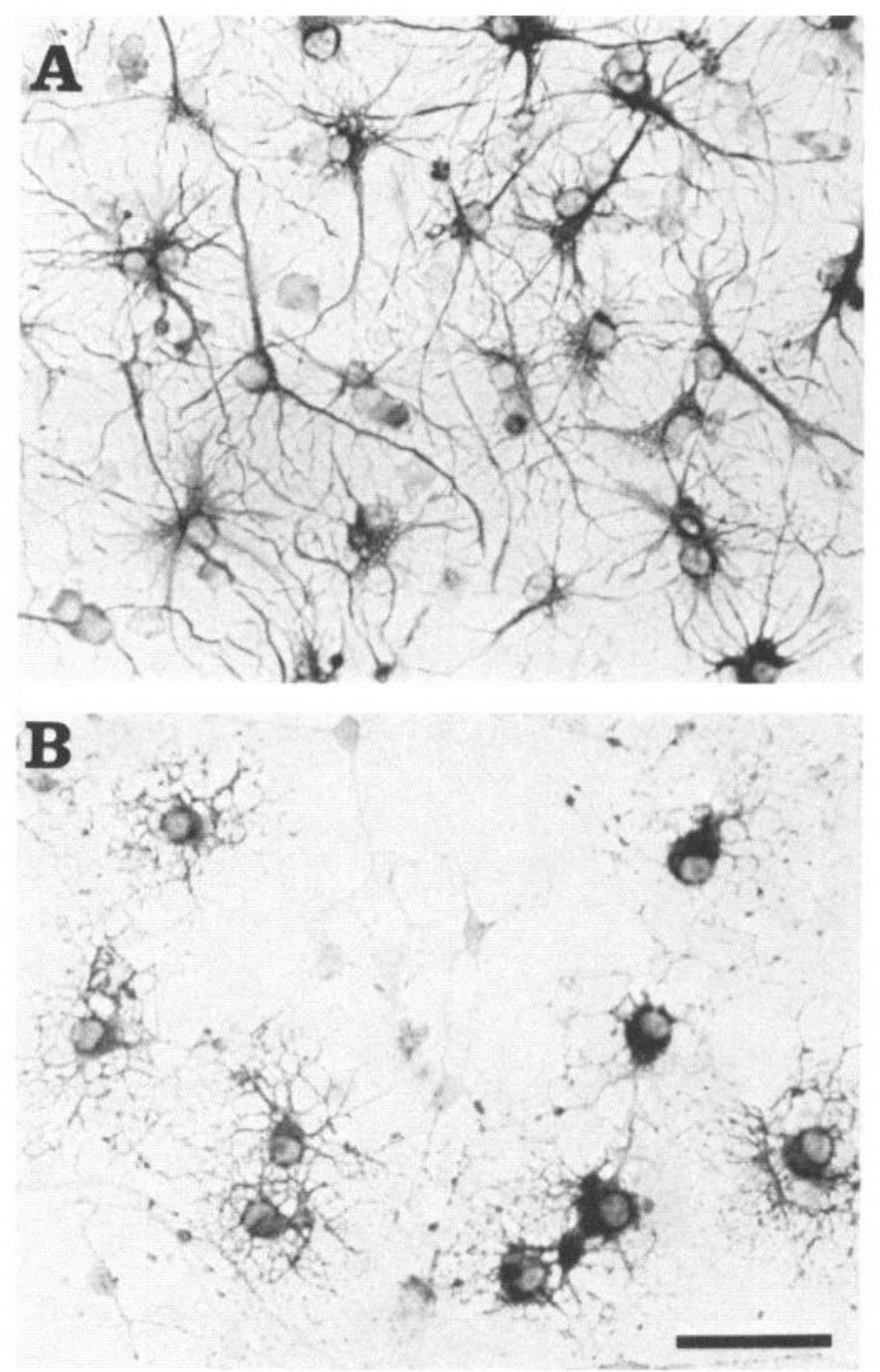

Figure 6. Morphology of GFAP-IR astrocytes $(A)$ and CNP-IR oligodendrocytes $(B)$ replated from aFGF and heparin-treated mesencephalic cultures. E14.5 mesencephalic cultures were treated with aFGF $(50 \mathrm{ng} / \mathrm{ml})$ and heparin $(2.5 \mathrm{U} / \mathrm{ml})$. After $7 \mathrm{~d}$, the stimulated cells were replated and grown another 4-6 d in serum-free N2 medium. Scale bar, $50 \mu \mathrm{m}$.

The role of FGF as a neuronotrophic factor in the developing brain has been repeatedly proposed. The hypotheses is supported by the recent demonstration of high levels of mRNA coding for aFGF and bFGF, as well as the FGF receptor, in most areas of the embryonic brain (Ernfors et al., 1990; Heuer

Table 3. Effect of glial CM on number of NF-IR neurons

\begin{tabular}{ll} 
Treatment & $\begin{array}{l}\text { NF-IR } \\
\text { neurons } / \mathrm{cm}^{2}\end{array}$ \\
\hline Control & $23,920 \pm 2623$ \\
Glial CM & $23,520 \pm 763$ \\
Glial CM $+{ }^{3}$ H-Thymidine & $22,933 \pm 230$
\end{tabular}

E14.5 mesencephalic cultures were established as described in Figure 1 and treated with $60 \%$ of glial $\mathrm{CM}$. On day 2 , cultures were treated for $24 \mathrm{hr}$ with ${ }^{3} \mathrm{H}$-thymidine $(4 \mu \mathrm{Ci} / \mathrm{ml})$. After $7 \mathrm{DIV}$, the number of NF-IR neurons was determined in five randomly chosen observation fields per well (total area, $1.25 \mathrm{~mm}^{2}$ ) and corrected to $1 \mathrm{~cm}^{2}$. Values are expressed as mean $\pm \operatorname{SD}(n=3)$. 


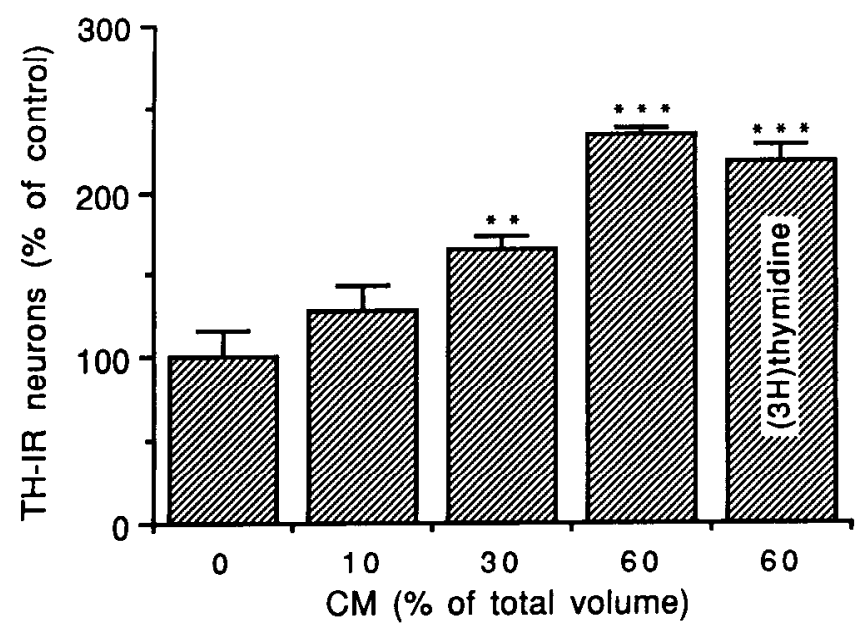

Figure 7. Effect of medium conditioned by aFGF and heparin-stimulated mesencephalic glia on dopaminergic cell survival. CM was obtained by incubating aFGF and heparin-stimulated glia, after replating, for $48 \mathrm{hr}$ with serum-free $\mathrm{N} 2$ medium. Effects of various concentrations of glial CM on the number of surviving TH-IR neurons in E14.5 mesencephalic cultures were assessed after $7 \mathrm{DIV} .{ }^{3} \mathrm{H}$ thymidine treatment $(4 \mu \mathrm{Ci} / \mathrm{ml}$ ) was carried out on day 2 of cultivation for $24 \mathrm{hr}$. Values are expressed as the mean $\pm \operatorname{SD}(n=4) .^{* *}, p \leq 0.01 ;^{* * *}, p \leq 0.001$.

et al., 1990; Wilcox and Unnerstall, 1991). Moreover, bFGF and aFGF have been found to support the survival of various CNS neurons in vitro, including hypothalamic, cortical, hippocampal, spinal cord, and mesencephalic dopaminergic neurons (Morrison et al., 1986; Walicke and Baird, 1988a,b; Unsicker ct al., 1987; Ferrari et al., 1988; Walicke, 1988; TorresAleman et al., 1990).

While evidence exists that FGF acts directly on neurons (Walicke and Baird, 1988a), other studies suggested that FGF has indirect effects on neuronal differentiation (Knusel et al., 1990). Several observations suggest that the neurotrophic effects exerted by aFGF and bFGF on cultured dopaminergic neurons are mediated by glial cells. First, in this study it was shown that the increase in dopaminergic neuronal survival after treatment of serum-free mesencephalic cultures with aFGF or hFGF is accompanied by a fourfold increase in the number of mesencephalic astrocytes. The higher labeling index of astrocytes in all these cultures for ${ }^{3} \mathrm{H}$-thymidine suggests that this increase resulted from a proliferation of glial precursors. Second, the concentrations of aFGF and bFGF of 5 and $3 \mathrm{ng} / \mathrm{ml}$, respectively, required for half-maximal survival of dopaminergic neurons are similar to the concentrations of both growth factors reported to affect glial proliferation and differentiation in cultures from other brain areas (Morrison et al., 1988; Perraud et al., 1988, 1990; Torres-Aleman et al., 1990). Third, the neurotrophic effects of aFGF and bFGF on mesencephalic dopaminergic neurons are mimicked by treating mesencephalic cultures with $\mathrm{CM}$ derived from mesencephalic glia previously stimulated with aFGF and heparin and replated in the virtual absence of neurons. Although the aFGF-induced glial cells were rinsed eight times between replating and collection of the $\mathrm{CM}$, the presence of residual exogenous aFGF in the glial CM cannot totally be ruled out; however, it is unlikely that concentrations sufficient to affect dopaminergic cell survival $(>1 \mathrm{ng} / \mathrm{ml}) \mathrm{re}-$ mained. This is further supported by the finding that unlike aFGF, which increases both the number of dopaminergic neurons and the number of astrocytes in culture, the neurotrophic
Table 4. Immunocytochemical identification of cells stimulated by aFGF and heparin

\begin{tabular}{ll} 
Antiserum & $\begin{array}{l}\text { Number of } \\
\text { immunoreactive } \\
\text { cells/1000 } \\
\text { plated cells }\end{array}$ \\
\hline Anti-vimentin & $629 \pm 34$ \\
Anti-CNP & $150 \pm 6$ \\
Anti-GFAP & $337 \pm 18$ \\
Anti-NF & $9 \pm 1$ \\
Anti-LCA (Ox1) & 0 \\
Anti-fibronectin & 0
\end{tabular}

Cells stimulated by aFGF and heparin in EI4.5 mesencephalic cultures were replated, grown for $4 \mathrm{~d}$ in serum-free $\mathrm{N} 2$ medium, and stained with the indicated antisera. Values are expressed as the mean $\pm \operatorname{SD}(n=4)$.

effect of the glial CM is not paralleled by an increase in glial cell number. Moreover, the neurotrophic effects of the glial CM persist in cultures with inhibited glial proliferation. These observations suggest that the neurotrophic activity acts directly on mesencephalic neurons and is due to a substance of unknown identity. Furthermorc, the absence of any effect of the glial CM on the number of NF-IR neurons suggests that the factor(s) contained in this CM acts specifically on dopaminergic neurons. However, this does not exclude the possibility that the differentiation of other populations of neurons is affected and that these changes are not detected by counting NF-IR neurons. Finally, the neurotrophic effects of aFGF and bFGF on dopaminergic neurons are abolished when glial proliferation is inhibited with high doses of ${ }^{3} \mathrm{H}$-thymidine. The absence of any influences of the ${ }^{3} \mathrm{H}$-thymidine treatment on the number of dopaminergic neurons in control cultures excludes the possibility that the treatment itself interferes with dopaminergic cell survival per se. It has been reported previously that aFGF and bFGF are mitogens for neuronal precursor cells (Gensburger et al., 1987; Murphy et al., 1990). However, we observed that the total number of neurons does not decrease in cultures in which proliferating cells are killed with high concentrations of tritiated thymidine $(4 \mu \mathrm{Ci} / \mathrm{ml})$. Moreover, cultivated mesencephalic neurons do not express nuclear ${ }^{3} \mathrm{H}$-thymidine labeling (using $1 \mu \mathrm{Ci}$ / $\mathrm{ml}$ of the isotope) in a $48 \mathrm{hr}$ chase experiment (Engele and Bohn, unpublished observations). These observations suggest that neuroblasts are not proliferating under our culture conditions and exclude the possibility that ${ }^{3} \mathrm{H}$-thymidine treatment reduces the number of dopaminergic neurons in aFGF- or bFGF-treated cultures by inhibiting proliferation of dopaminergic precursors.

Previous studies have also shown that aFGF and bFGF additively support the survival of hippocampal neurons (Walicke and Baird, 1988b). However, in our system aFGF and bFGF have no additive effects on dopaminergic cell survival, suggesting that the survival-promoting action of both growth factors involves a similar, glial-mediated mechanism. Our previous experiments showing that survival of dopaminergic neurons is twofold higher in mescncephalic cultures treated with conditioned medium from several glial tumor cell lines than in these experiments (Engele et al., 1991) further suggest that the absence of such additive effects is not limited by the original number of dopaminergic neurons plated.

PDGF and interleukin-1 are potent mitogens for cultured O-2A progenitor cells of the optic tract and cortical astrocytes (Giulian et al., 1988; Richardson et al., 1988). The observation that neither of these growth factors stimulates proliferation or 
differentiation of embryonic mesencephalic glia suggests that their growth-promoting action may be region specific and/or age dependent.

The identity of the active substance(s) released from the mesencephalic glia remains unknown; however, it appears to be some substance(s) other than aFGF, bFGF, PDGF, or interleukin-1. One possibility is brain-derived neurotrophic factor (BDNF), which recently has been reported to act on mesencephalic dopaminergic neurons (Hyman et al., 1991; Knüsel et al., 1991). It also remains to be determined whether the neurotrophic support exerted by aFGF and bFGF on dopaminergic neurons results from the increased concentration of a neuroactive substance(s) in culture due to the stimulation of glial proliferation or whether the growth factors induce synthesis and/ or release of neuroactive substances. Such regulatory influences on glial cells have recently been shown to be exerted by interleukin- 1 and bFGF, which upregulate glial mRNA coding for NGF (Hellendall et al., 1990; Vige and Wise, 1990).

The heterogeneity of cells in primary mesencephalic cultures and in cultures obtained by replating aFGF-stimulated glia did not allow an identification of the cellular source of this neurotrophic activity. It is unlikely, however, that neurons represent this source since their number is extremely low in the replated cells. It can further be excluded that these neurotrophic activities derive from fibroblasts or microglia, cell types not detectable in this culture system. Our previous experiments showing that the neurotrophic effects on dopaminergic neurons exerted by $\mathrm{CM}$ derived from several glial tumor cell lines are all paralleled by increases in the number of fibrous astrocytes focus attention on astrocytes as likely to be involved in this neurotrophic interaction. Studies demonstrating that dendritic development of dopaminergic neurons is induced in cocultures with mesencephalic astrocytes also support this hypothesis (Chamak et al., 1987).

In summary, our results suggest that in addition to direct actions on neurons, growth factors can influence neuronal survival and differentiation through glial-mediated processes. The demonstration that growth factors can affect neuronal development indirectly not only emphasizes the complexity of cellcell interactions during development but also suggests that similar interactions may also play an important role in the maintenance and regeneration of neuronal structures in the adult brain.

\section{References}

Banker GA (1980) Trophic interactions between astroglial cells and hippocampal neurons in culture. Science 209:809-810.

Barbin G, Selak I, Manthorpe M, Varon S (1984) Use of central neuronal cultures for the detection of neuronotrophic agents. Neuroscience 12:33-43.

Bottenstein JE, Sato GH (1979) Growth of a rat neuroblastoma cell line in serum-free supplemented medium. Proc Natl Acad Sci USA 76:514-517.

Chamak B, Fellows A, Glowinski J, Prochiantz A (1987) MAP2 expression and neuritic outgrowth and branching are coregulated through region-specific neuro-astroglial interactions. J Neuorsci 7:3163-3170.

Engele J, Pilgrim C, Kirsch M, Reisert I (1989) Different developmental potentials of diencephalic and mesencephalic dopaminergic neurons in vitro. Brain Res 483:98-109.

Engele J, Schubert D, Bohn MC (1991) Conditioned media derived from glial cell lines promote survival and differentiation of dopaminergic neurons in vitro: role of mesencephalic glia. J Neuorsci Res, in press.
Ernfors P, Lönnerberg P, Ayer-LeLievre C, Persson H (1990) Developmental and regional expression of basic fibroblast growth factor mRNA in the rat central nervous system. J Neurosci Res 27:10-15.

Feinendegen LE (1967) Tritium-labeled molecules in biology and medicine. New York: Academic.

Ferrari G, Minozzi M-C, Toffano G, Leon A, Skaper SD (1989) Basic fibroblast growth factor promotes the survival and development of mesencephalic neurons in culture. Dev Biol 133:140-147.

Gensburger C, Labourdette G, Sensenbrenner M (1987) Brain basic fibroblast growth factor stimulates the prolifcration of rat ncuronal precursor cells in vitro. FEBS Lett 217:1-5.

Giulian D., Young DG, Woodward J, Brown DC, Lachman LB (1988) Interleukin-1 is an astroglial growth factor in the developing brain. J Neurosci 8:709-714.

Hatanaka H, Tsukui H (1986) Differential effects of nerve-growth factor and glioma-conditioned medium on neurons cultured from various regions of fetal rat central nervous system. Dev Brain Res $30: 47-56$.

Hatten ME, Lynch M, Rydel RE, Sanchez J, Joseph-Silverstein J, Moscatelli D, Rifkin DB (1988) In vitro neurite extension by granule neurons is dependent upon astroglial-derived fibroblast growth factor. Dev Biol 125:280-289.

Hefti F, Hartikka J, Knusel B (1989) Function of neuronotrophic factors in the adult and aging brain and their possible use in the treatment of neurodegenerative diseases. Neurobiol Aging 10:515533.

Hellendal RP, Casper D, Lackner C, Berkenbosch F, Blum M (1990) Regulation of nerve growth factor mRNA by interleukin- 1 in the rat central nervous system. Soc Neurosci Abstr 16:825.

Heuer JG, von Bartheld CS, Kinoshita Y, Evers PC, Bothwell M (1990) Alternating phases of FGF receptor and NGF receptor expression in the developing chicken nervous system. Neuron 5:283-296.

Hyman C, Hofer M, Barde Y-A, Juhasz M, Yancopoulos GD, Squinto SP, Lindsay RM (1991) BDNF is a neurotrophic factor for dopaminergic neurons of the substantia nigra. Nature 350:230-232.

Knusel B, Michel PP, Schwaber JS, Hefti F (1990) Selective and nonselective stimulation of central cholinergic and dopaminergic development in vitro by nerve growth factor, basic fibroblast growth factor, epidermal growth factor, insulin and the insulin-like growth factors I and II. J Neurosci 10:558-570.

Knüsel B, Winslow JW, Rosenthal A, Burton LE, Seid DP, Nikolics K, Hefti $F$ (1991) Promotion of central cholinergic and dopaminergic neuron differentiation by brain-derived neurotrophic factor but not by neurotrophin 3. Proc Natl Acad Sci USA 88:961-965.

Lindsay RM (1979) Adult rat brain astrocytes support survival of both NGF-dependent and NGF-insensitive neurones. Nature 282:80-82.

Manthorpe M, Varon S, Adler R (1981) Neurite-promoting factor in conditioned medium from RN22 Schwannoma cultures: bioassay, fractionation, and properties. $J$ Neurochem 37:759-767.

Morrison RS, Sharma A, deVellis J, Bradshaw RA (1986) Basic fibroblast growth factor supports the survival of cerebral cortical neurons in primary culture. Proc Natl Acad Sci USA 83:7537-7541.

Morrison RS, Keating RF, Moskal JR (1988) Basic fibroblast growth factor and epidermal growth factor exert differential trophic effects on CNS neurons. J Neurosci Res 21:71-79.

Murphy M, Drago J, Barlett PF (1990) Fibroblast growth factor stimulates the proliferation and differentiation of neural precursor cells in vitro. J Neurosci Res 25:463-475.

Neufeld G, Gospodarowicz D, Dodge L, Fujii DK (1987) Heparin modulation of the neurotropic effects of acidic and basic fibroblast growth factors and nerve growth factor on PC12 cells. J Cell Physiol 131:131-140.

O'Malley EK, Black IB, Dreyfus CF (1989) Dopaminergic cell number is selectively increased by substantia nigra support cells in vitro. Soc Neurosci Abstr 15:1260.

Perraud F, Labourdette G, Miehe M, Loret C, Sensenbrenner M (1988) Comparison of the morphological effects of acidic and basic fibroblast growth factors on rat astroblasts in cultures. J Neurosci Res 20:1-11.

Perraud F, Labourdette G, Eclancher F, Sensenbrenner M (1990) Primary cultures of astrocytes from different brain areas of newborn rats and effects of hasic fibroblast growth factor. Dev Neurosci 12:11-21.

Pruss RM, Bartlett PF, Gavrilovic J, Lisak RP, Rattray S (1982) Mitogens for glial cells: a comparison of the response of cultured astrocytes, oligodendrocytes and Schwann cells. Dev Brain Res 2:19-35.

Reisert I, Engele J, Pilgrim C (1989) Early sexual differentiation of 
diencephalic dopaminergic neurons of the rat in vitro. Cell Tissue Res 255:411-417.

Richardson WD, Pringle N, Mosley MJ, Westermark B, Dubois-Dalcq M (1988) A role of platelet-derived growth factor in normal gliogenesis in the central nervous system. Cell 53:309-319.

Schnitzer J, Franke WW, Schachner M (1981) Immunocytochemical demonstration of vimentin in astrocytes and ependymal cells of developing and adult mouse nervous system. J Cell Biol 90:435-447.

Thoenen H, Barde Y-A, Davies AM, Johnson JE (1987) Neurotrophic factors and neuronal death. In: Selective neuronal death, Ciba Foundation symposium 126, pp 82-95. Chichester: Wiley.

Torres-Aleman I, Naftolin F, Robbins RJ (1990) Trophic effects of basic fibroblast growth factor on fetal rat hypothalamic cells: interactions with insulin-like growth factor I. Dev Brain Res 52:253-257.

Unsicker K, Reichert-Preibsch H, Schmidt R, Pettmann B, Labourdette $G$, Sensenbrenner M (1987) Astroglial and fibroblast growth factors have neurotrophic functions for cultured peripheral and central nervous system neurons. Proc Natl Acad Sci USA 84:5459-5463.
Vige X, Wise BC (1990) Mechanism of NGF mRNA regulation by interleukin-1 and basic fibroblast growth factor in rat astrocytes. Soc Neurosci Abstr 16:297.

Walicke PA (1988) Basic and acidic fibroblast growth factors have trophic effects on neurons from multiple CNS regions. J Neurosci 8: 2618-2627.

Walicke PA, Baird A (1988a) Neuronotrophic effects of basic and acidic fibroblast growth factors are not mediated through glial cells. Dev Brain Res 40:71-79.

Walicke PA, Baird A (1988b) Trophic effects of fibroblast growth factor on neural tissue. In: Progress in brain research, Vol 78 (Gash D, Sladek JR, eds), pp 333-338. Amsterdam: Elsevier.

Whittemore SR, Seiger A (1987) The expression, localization and functional significance of beta-nerve growth factor in the central nervous system. Brain Res Rev 12:439-464.

Wilcox BJ, Unnerstall JR (1991) Expression of acidic fibroblast growth factor mRNA in developing and adult rat brain. Neuron 6:397-409. 